\title{
Problem based learning: a model in teaching English at junior high school
}

\section{Isrokijah}

State Junior High School 3 Tulungagung, Indonesia

isrokijah@yahoo.com

*) correspondence: isrokijah@yahoo.com

\begin{abstract}
Problem Based Learning (PBL) is one of teaching models required in Curriculum 2013. However, not many teachers apply it in teaching English. This happens because of their lack of knowledge about PBL and how to apply it in the class. This article aims at elaborating how to implement problem based learning (PBL) as an effective model in teaching and learning English at junior high school. By knowing how to apply PBL in the classroom, it is hoped that the teachers will be motivated to use PBL in their teaching English, PBL increases students' motivation in learning, their ability to work independently and collaboratively with others, and their problem solving skills in order that the English learning objectives can be achieved.
\end{abstract}

Key words: problem based learning (PBL); teaching English; junior high school

\section{INTRODUCTION}

Curriculum 2013 or it is usually called K-13 has been implemented for some years. As stated in Permendikbud Number 68/2013 the mastery of English is crucial requirement in responding to the challenge of the era. In other words, the teaching of English plays an important role in preparing the students to get access to international communication in the globalization era, especially the coming era of free trade market. Therefore, students must have a good English ability. In Curriculum 2013 the four English skills: listening, speaking, reading, and writing are presented integrated.

Problem-Based Learning (PBL) is one of learning models required to be implemented in the teaching and learning process. As stated by the Ministry of Education and Culture of Indonesia in the material of teacher training in Curriculum 2013, Problem-Based Learning presented contextual problem which stimulated the students to learn. In PBL situation, the students integrated knowledge and skills simultaneously and applied them in relevant context. However, most teachers do not really know how to apply PBL in their teaching and learning process at junior high school.

To achieve learning objective, teaching materials and teaching models cannot be separated. They should be well suited (Widodo, 2005). Therefore the available of well-prepared materials is very helpful. Moreover, to successfully conduct Problem-Based Learning (PBL) in teaching English, well prepared teaching materials are crucial. It will be better if teachers can design PBL worksheets to run the teaching model. With the worksheets the students conducted meaningful learning. They learned to solve the problem by implementing their knowledge or trying to explore the knowledge they needed (Isrokijah, 2015).

PBL is often heard in teaching English, however, not many teachers know what it is and how to apply in the classroom especially at junior high school level in which students just have studied a little bit language components and language skills. In addition, PBL has never been discussed in any teacher workshops.

Beginning from that fact, this article will elaborate how to apply PBL model at junior high school in detail. 


\section{RESULTS AND DISCUSSION}

\section{Teaching English at Junior High School}

English is a compulsory subject to study at junior high school. It means that students have to pass the course. In Curriculum 2013 English has 4 teaching hours in a week for each grade. Different from previous curriculum, in Curriculum 2013 the four language skills: listening, speaking, reading, and writing are performed simultaneously. Learning objectives are also arranged based on basic competences.

English syllabus contains core competences, basic competences, core materials, learning activities, and assessment. There are four core competences. The first core competence deals with spiritual competences. The second core competences deal with social competence. The third core competences deal with knowledge competences. And the fourth core competences deal with skill competences.

Teaching English at junior high school is conducted based on basic competences stated on the English syllabus which has designed by the government. Basic competences are language skills; listening, speaking, reading, and writing, to be learned by students. There are two basic competences, knowledge and skill. Higher grade has more basic competences than lower grade.

The core materials as well as learning activities are also available on the syllabus. The core materials include language components, such as grammar, vocabulary, spelling, pronunciation, genre texts, such as descriptive, recount, narrative, report, and procedure texts, and short functional text, such as notice, short message, greeting card, label, and advertisement, etc. In this case, teachers have authority to develop them suited with the teaching model and method applied. There are three instructional models required by the government, discovery learning, problem based learning, and project based learning. For teaching method teachers can apply any kinds of method based the basic competences and the core materials. However, they are supposed to use method which performs cooperative learning and a student-centered learning.

\section{What is Problem-Based Learning (PBL)?}

Problem-based learning (PBL) is an educational approach whereby a problem is the starting point of the learning process (Graaff \& Annette, 2003). Problem-based learning (PBL) initiates students' learning by creating an authentic problem to solve. In PBL courses students learn through facilitated problem solving process. During problem solving process students construct content knowledge, develop self-directed learning skills as well as high order thinking skill which is cognitive skill required to develop problem solving, reasoning, communication, and self-assessment skills.

Improving problem solving skill is main focus of PBL. Learning is a student-centered in which students learn how to think and learn independently. Through problem solving activity students learn to apply critical thinking to solve complex problems that do not have a single correct answer. Therefore the activation of prior knowledge is very helpful. Group members may activate their prior knowledge and accumulate new knowledge to identify and solve the problems. Norman \& Schmidt (1992) add in group discussion, members' contributions of elaborated knowledge are valuable for they formulate creative ideas and they facilitate the discovery of possible solutions.

Moreover, Huang \& Wang (2012) state that the ultimate goals of PBL are to help learners elevate intrinsic motivation, build up thinking skills, develop higher level knowledge, and become self-guided learners who could cooperate and collaborate in groups. Therefore, PBL model promotes students' confidence and thinking skill in problem solving and makes them self-directed students.

\section{Advantages and Disadvantages of PBL}

Applying PBL in teaching English at junior high school has some advantages and disadvantages. The advantages are as follows:

1. PBL is very effective to improve learners' critical thinking skill. Learners will try to think hard to solve a problem which does not have a single answer presented by the teacher.

2. Learners will be accustomed to solve a problem since they have been trained in the class. It can enhance their problem solving skill. 
3. PBL can be applied both in large or small classes. In this case, learners always work in group discussion.

4. PBL works well with mixed-ability classes. It is students-centered. They can learn from one another.

In addition to such advantages, PBL has also disadvantages, as follows:

1. Students are not used to such thing that makes them embarrassed to express their idea. It is influenced by the previous way of teaching. Teachers often explain much and students just listen to them and take notes and do some exercises.

2. Group work often gets stuck. Therefore, teachers should act as good facilitators. Guidance is needed when group discussion is going on.

3. It is not suitable for lower level students. They have not learned enough language components and language skills. For junior high school level PBL can be applied starting from grade 8 students.

4. Only some particular basic competences can apply PBL. Therefore, teachers should be selective in choosing the appropriate basic competences.

\section{The Application of Problem Based Learning (PBL) in the Classroom}

As stated above that teaching English at junior high school is based on basic competences. For grade 8 PBL can be used to teach English in the class, especially for basic competences related to:

1. Grammar (degree of comparison, simple present tense, simple past tense)

2. Genre texts (descriptive, recount, procedure, narrative, and report texts)

3. Short functional texts (notice, short message, label, advertisement)

Problem solving is the prominent classroom activity in Problem-Based Learning. It is typically geared to highlight the students' high order thinking skill. In this sense, students play main role: a speaker and a listener, or a writer and a reader. They listen attentively and give respond whenever they need to do it.

In using PBL in the class teachers must be creative in designing the classroom activity scenario. Since students' textbook presents simple and minimum materials students are supported to use any learning sources, such as internet. It will be very helpful if teachers prepare worksheets for the students. Worksheets are developed to support textbook or course of instruction which function to provide exercises for the mastery of specific skills or content (Isrokijah, 2015).

The following are sample materials and steps in applying PBL in grade 8:

\section{Basic competence:}

3.9 applying social functions, text structures, and language elements of oral and written transactional interaction texts that involve the act of giving and asking for information related to the comparison of the number and nature of people, animals, objects, according to context of their use. (Note the language element degree of comparison)

4.9 Composing short and simple transactional interaction texts that involve the act of giving and asking for information related to the comparison of the number and nature of people, animals, objects by paying attention to the social functions, text structures, and language elements that are correct and in context.

\section{Learning objectives:}

After learning this chapter, the students are able to:

1. Write short paragraphs containing a topic sentence and supporting sentences.

2. Present short paragraphs orally in power point.

Core material: adjective (big, small, strong, wild, large, short, tall)

Procedures:

1. Prepare language support containing vocabulary and grammar exercises. Students do the exercises in pairs.

Vocabulary Exercise 
Task 1 Complete the sentences with the right word in the box!

\begin{tabular}{rrrrr}
\hline Alligators & Jaw & Tooth & Mouths & Keen \\
\hline Fast & Hold & Hunt & Rare & Live \\
\hline
\end{tabular}

1) Crocodiles look like ....

2) An alligator's ... is U-shaped.

3) When a crocodile loses a ..., it is quickly replaced.

4) To keep cool, they open their ... in a process that is called "mouth gaping".

5) Crocodiles also have very ... hearing.

6) Crocodiles are very ... swimmers.

7) They can ... their breath underwater for around one hour.

8) It is illegal to ... crocodiles for their skin.

9) This makes their skin very ....

10) Alligators prefer to ... in freshwater areas.

\section{Grammar Exercise}

Task 2 Complete the sentences with the right form of comparison!

1) A crocodile is ... (big) than an alligator.

2) On land, crocodiles aren't nearly ... (fast) than in water.

3) A crocodile has ... (strong) jaws than a human's.

4) Crocodiles have the ... (good) hearing that they can hear their babies calling from inside their egg.

5) Komodo dragons are the ... (large) living lizards in the world.

6) Komodo dragons are as ... (rare) as crocodiles.

7) Which is ... (wild), a komodo dragon or a crocodile?

8) Gorillas are the ... (large) of the apes in the world.

9) Gorillas' legs are ... (short) than human legs.

10) And their arms are ... (long) than human arms.

Task 3 Rearrange these jumbled words into a correct sentence!

1. Is - the - taller - horse -The - than - camel

Answer

2. The - heavier - hippo - The - bear - is - than

Answer

3. Animals - The - among - runs - other - cheetah - fastest

Answer

4. Than - is - The - dolphin - smaller - whale - the

Answer

5. Than - the - turtle - mouse - is - The - slower

Answer

6. Giraffe - tallest - the - The - is - animal

Answer

7. Wilder - is - lion - The - the - horse - than

Answer 
8. Whale - is - the - biggest - The - blue - others - among Answer

9. Prettiest - the - peacock - is - The - bird

Answer

10. The - donkey - stronger - than - horse - The - is

Answer

2. Based on the exercises students are led to draw conclusion or make summary of what they have done.

SUMMARY: To compare two things we can use sentences as follows:

1) A turtle is as slow as a snail.

2) A snake is longer than an eel.

3) A monkey is more dangerous than a cat.

4) An elephant is the biggest animal in the world.

5) A butterfly is the most beautiful among other insects.

3. After students have got basic knowledge in vocabulary and grammar, procedures of PBL can be carried out.

1) It is started with warm-up activity.

Task 1. Answer these questions with your partner!

a. What do you know about a komodo dragon?

Answer

b. What category does it belong to?

Answer

c. What are the other names for a komodo dragon?

d. Answer

Followed by problem posing activity

Task 2. Study this context with your partner, then create the problems!

The Komodo National Park is a national park in Indonesia located within the Lesser Sunda Islands in the border region between the provinces of East Nusa Tenggara and West Nusa Tenggara. The park includes the three larger islands Komodo, Padar and Rinca, and 26 smaller ones, with a total area of $1,733 \mathrm{~km}^{2}\left(603 \mathrm{~km}^{2}\right.$ of it land). The national park was founded in 1980 to protect the Komodo dragon, the world's largest lizard.

Source: http://en.wikipedia.org/wiki/Komodo_National_Park 
Talking about komodo dragons, what do you want to know more about them? Make questions by filling the following map!

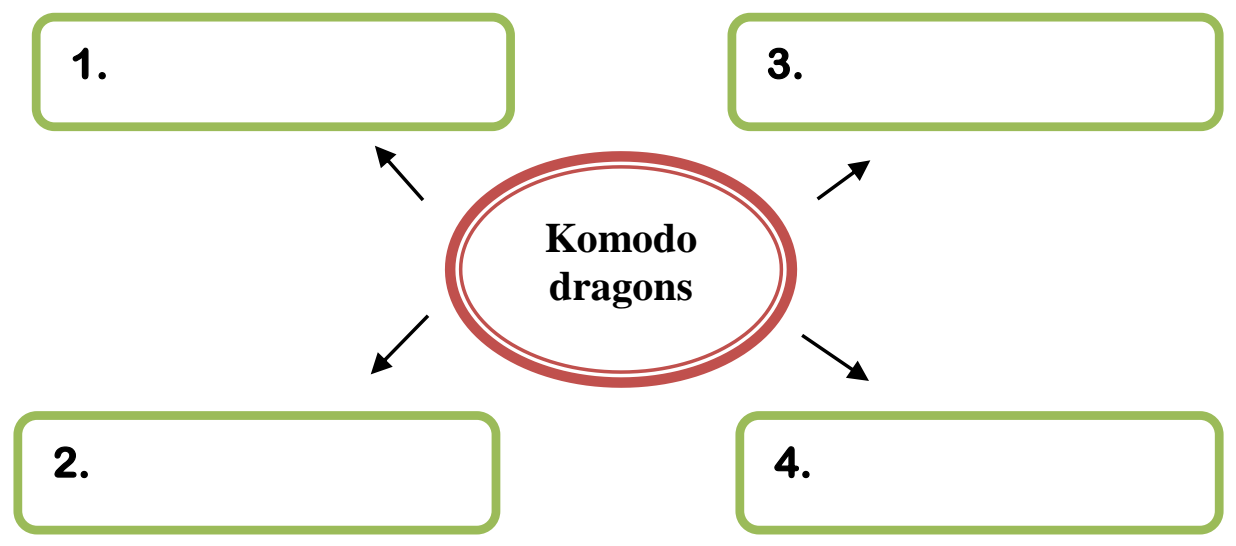

\section{2) Next, procedures for problem solution}

STEPS TO SOLVE THE PROBLEMS:

1. Divide your class into 4 groups.

2. Browse in the internet website related to the topic to find relevant information

3. Read magazines/books related to the topic

4. After all the information is collected, analyze it with your group

\section{TASK COMPLETION RULES}

1. Submit your group work in the form of:

a. A written descriptive report

b. A power-point presentation

2. Presentation: Max: 10 minutes

3. Due date: next meeting.

\section{3) Then, worksheet to complete the task}

After you have collected relevant information, write down the data as follows:

a. From the internet you get:

For problem 1:

For problem 2:

For problem 3:

For problem 4:

b. From the magazines and other books you get:

For problem 1:

For problem 2:

For problem 3:

For problem 4: 
Based on the data you found above, write your descriptive report on the following part! For problem 1:

Topic sentence:

Supporting sentences:

For problem 2:

Topic sentence:

Supporting sentences:

For problem 3:

Topic sentence:

Supporting sentences:

For problem 4:

Topic sentence:

Supporting sentences:

\section{2) The activity is ended with group presentation}

Task 4. Present your group work on a power point!

Other groups should pay attention to the information presented and may ask questions when they do not understand.

\section{CONCLUSIONS AND SUGGESTIONS}

When PBL is applied teachers have to make two kinds of preparation. First, preparation for preactivity includes selecting the appropriate basic competence, formulating learning objectives, designing exercises for language support. Second, preparation for PBL activity includes designing warm-up activity, main activity and closing activity. Good preparation will support the teachers in applying PBL in teaching English.

The application of PBL emphasizes on improving problem solving skill. It means that content knowledge and critical thinking skill of the learners will improve too. PBL promotes students' confidence in their problem solving skills and strives to make them self-directed learners. These skills can put PBL students at an advantage in future courses and in their careers. While such confidence does not come immediately, it can be fostered by good instruction. Teachers who provide a good learning community in the classroom, with positive teacher-student and student-student relationships, give students self-confidence over their learning, develop their meaningful learning methods and empower students with problem solving skills that will enhance their motivation to learn.

Since PBL model needs long time periods of time it is recommended that the teachers are wellprepared so that the group work will run well and the learners will enjoy doing it.

Most importantly, when the learners get stuck in their group discussion or group presentation the teachers are required to give motivation and support to them, and then lead them to find solutions of the problem. 


\section{REFERENCES}

Bridges, E. M., \& Hallinger, P. (1999). The use of cases in problem based learning. Journal of Cases in Educational Leadership, 2 (2), 1- 6.

https://www.researchgate.net/publication/249786488_The_Use_of_Cases_in_Problem_Based _Learning

Duch, B. J., Groh, S. E., and Allen, D. E. (2001). The Power of Problem-Based Learning. VA: Stylus.

Graaff, E. de, and A. Kolmos (2003). Characteristic of Problem Based Learning. Int. J. Engng Ed., 19 (5), 657- 662. https://www.ijee.ie/articles/Vol19-5/IJEE1450.pdf

Hmelo-Silver, C. E. (2004). Problem-Based Learning: What and How Do Students Learn? 16 (3), 235-266. https://www.researchgate.net/publication/226053277_Problem-

Based_Learning_What_and_How_Do_Students_Learn

Huang, K. \& Wang, T. (2012). Applying Problem-based Learning (PBL) in University English Translation Classes. The Journal of International Management Studies. 7 (1), 121-127. http://www.jimsjournal.org/13\%20Tzu-Pu\%20Wang.pdf

Isrokijah, 2015. Developing Problem-Based Learning (PBL) Worksheets for Junior High school students. Islamic University of Malang: Unpublished Master's Thesis.

Kemendikbud. 2013. Kompetensi Dasar Sekolah Menengah Pertama (SMP)/Madrasah Tsanawiyah (MTs). http://pubilkasipendidikan.blogspot.com/2013/02/kompetensi-inti-dan-kompetensidasar.html

Norman \& Schmidt (1992). The Psychological Basis of Problem-Based Learning: A Review of the Evidence. 67 (9), 557-65.

https://journals.lww.com/academicmedicine/Abstract/1992/09000/The_psychological_basis_ of_problem_based_learning_.2.aspx

Savery, J. R \& Duffy, T. M. (1995). Problem-based learning: An instructional model and its constructivist framework. Educational Technology, 35 (5), 31-38.

https://eric.ed.gov/?id=EJ512183

Simerci, N. (2005). The Effects of Problem-Based Learning on the Academic Achievement of Students in Development and Learning. 14 (4), 415-425.

https://www.researchgate.net/publication/234665542_The_Effects_of_Problem-

Based_Learning_on_the_Academic_Achievement_of_Students_in_Development_and_Learnin $\mathrm{g}$

Widodo, H. P. (2005). Teaching Children Using a Total Physical Response (TPR) Method:

Rethinking. 33 (2), 235-249, http://sastra.um.ac.id/wp-content/uploads/2009/10/Teaching-

Children-Using-a-Total-Physical-Response-TPR-Method-Rethinking-Handoyo-Puji-

Widodo.pdf 